\title{
RAl1 wt Allele
}

National Cancer Institute

\section{Source}

National Cancer Institute. RA/1 wt Allele. NCI Thesaurus. Code C75454.

Human RAI1 wild-type allele is located in the vicinity of 17 p11.2 and is approximately 130 $\mathrm{kb}$ in length. This allele, which encodes retinoic acid-induced protein 1, plays roles in transcriptional regulation, development, control of body weig ht and complex behavioral responses. Mutations in this gene are associated with Smith-Magenis Syndrome. 